\title{
Assessment of Challenges in Export Marketing: The Case of Ethiopian Vegetable and Fruit Commercial Growers
}

\author{
Mohammed Alebachew Sisay \\ Marketing Management Department, Unity University, Addis Ababa, Ethiopia \\ Email: mohammedaleb@gmail.com
}

How to cite this paper: Sisay, M.A. (2018) Assessment of Challenges in Export Marketing: The Case of Ethiopian Vegetable and Fruit Commercial Growers. iBusiness, 10, 1-20.

https://doi.org/10.4236/ib.2018.101001

Received: November 28, 2017

Accepted: March 3, 2018

Published: March 6, 2018

Copyright $\odot 2018$ by author and Scientific Research Publishing Inc. This work is licensed under the Creative Commons Attribution International License (CC BY 4.0).

http://creativecommons.org/licenses/by/4.0/

cC) (i) Open Access

\begin{abstract}
Globalization forces companies to internationalize their operation in the global market. Exporting plays a vital role in economic development of a nation as well as for the development of the particular exporting company. Although, the benefits derived from exporting in an increasingly globalized marketplace are enormous, but for many companies, exporting is constrained by numerous challenges. The purpose of the study was to assess export marketing challenges of Ethiopian vegetable and fruit commercial growers. The study investigated 20 Ethiopian vegetable and fruit commercial growers and 8 stakeholders with questionnaires and interviews. The research utilized a mixed research design and analysis techniques specifically concurrent embedded approach. It is found out that the Ethiopian vegetable and fruit commercial growers export volume and sales lacks consistency and constrained by different challenges. Of the major challenges which were classified as internal barriers and external barriers, macro environmental barriers highly affected the growers. Local investors were highly affected by both the internal and external problems whereas foreign and joint ventures are affected in some extent with those problems. Less experienced growers were highly affected by the export problems than those who are more experienced. Management commitment problem; technological advancement problem; financial; lack of accessible transport system; low awareness of stakeholders; seasonality of Ethiopian supply; shortage of cargo; shortage of infrastructure; government bureaucracy; lack of potential markets; and shortage of inputs were identified as problems for the vegetable and fruit export. Therefore, to minimize these problems creating enabling policy environment; fair and competitive air freight cost; the growers to incorporate challenges in their export marketing strategy; the government to explore new markets, provide technical supports
\end{abstract}


and long-term loans to growers; to create new competitive input suppliers; integration of stakeholders of the sector; and to recruit skilled manpower are forwarded as recommendations.

\section{Keywords}

Marketing Challenges, Ethiopian Vegetable and Fruit Export, Export Challenges, Ethiopia, Export Marketing Challenges

\section{Introduction}

In the vegetables and fruit export marketing, authors have identified major challenges in the global arena; like post-harvest handling, food safety, quality, certification, competition [1] [2]. The challenges and opportunities were identified as internal and external [3] [4].

Many studies provide evidence about Ethiopian potential in the production and export of fruit and vegetable. Different authors mostly researched about the challenges and opportunities relating to the country's comparative advantages such as; wide range of altitude, suitable climate, abundant labor, vast land and water resources [5] [6].

Even though it started earlier, Ethiopia's current vegetable and fruit export is very limited as it started earlier than that of the late comer floriculture industry. Different authors described that its trend lacks consistency and characterized by a slight fluctuation year on year basis [7].

There is a deficiency in identifying export marketing related impediments in most of the literatures (Table 1). The marketing related impediments involved in the sector have not yet been empirically explored. Therefore, the statement of the problem of the study can be stated as what are the major export marketing related challenges.

The general objective of the study is to assess export marketing challenges of Ethiopian vegetable and fruit commercial growers.

The study will add new knowledge to the existing literature and it will be a stepping stone for academicians to carry out further studies on the issue. It will benefit existing growers and exporters to craft their marketing strategy based on the identified challenges and enhance their competitive position in the international market. It will also encourage non-exporting growers to engage themselves in the export. Moreover, it will be an input for policy makers to intensify and assess policies and regulations of the country in order to enhance the performance of the sector.

\section{Conceptual Framework}

The following conceptual framework is designed based on the literature review and the objective of the study (Figure 1). 
Table 1. Critically reviewed literatures.

\begin{tabular}{|c|c|c|c|c|c|c|}
\hline No & $\begin{array}{l}\text { Author(s) } \\
\text { Name(s) }\end{array}$ & $\begin{array}{c}\text { Title of the Journal } \\
\text { Article }\end{array}$ & $\begin{array}{l}\text { Research } \\
\text { Design }\end{array}$ & $\begin{array}{l}\text { Research } \\
\text { Context }\end{array}$ & Industry & Findings \\
\hline 1 & $\begin{array}{c}\text { Tesfom, G. \& Lutz } \\
\text { C. } 2006\end{array}$ & $\begin{array}{l}\text { A classification of } \\
\text { export marketing } \\
\text { problems of small \& } \\
\text { medium sized } \\
\text { manufacturing firms } \\
\text { in developing } \\
\text { countries }\end{array}$ & $\begin{array}{l}\text { Exploratory/ } \\
\text { Literature }\end{array}$ & $\begin{array}{l}\text { Developing } \\
\text { countries }\end{array}$ & $\begin{array}{l}\text { Small \& med. } \\
\text { manufacturing } \\
\text { firms }\end{array}$ & $\begin{array}{l}\text { The export problems are classified into } \\
\text { company barriers, product barriers, } \\
\text { industry barriers, export market barriers } \\
\text { and macro environment barriers. }\end{array}$ \\
\hline 2 & $\begin{array}{l}\text { Martinez, M. \& } \\
\text { Poole, N. } 2004\end{array}$ & $\begin{array}{l}\text { The development of } \\
\text { private fresh } \\
\text { produce safety } \\
\text { standards: } \\
\text { implications for } \\
\text { developing } \\
\text { Mediterranean } \\
\text { exporting countries }\end{array}$ & & $\begin{array}{l}\text { Developing } \\
\text { Mediterranean } \\
\text { exporting } \\
\text { countries }\end{array}$ & & $\begin{array}{l}\text { The major challenges faced by developing } \\
\text { countries as; meeting requirements } \\
\text { associated with the implementation of } \\
\text { high level sanitary or phytosanitary } \\
\text { measures, standards and conformity tests, } \\
\text { the lack and high cost of information, and } \\
\text { the resulting consequences for public } \\
\text { health are the fundamental justifications } \\
\text { for public intervention to improve food } \\
\text { safety, market barriers within advanced } \\
\text { economies to agricultural import. }\end{array}$ \\
\hline 3 & $\begin{array}{l}\text { Cass, A. \& Julian, } \\
\text { C.C. } 2003\end{array}$ & $\begin{array}{l}\text { Examining firm and } \\
\text { environmental } \\
\text { influences on export } \\
\text { marketing mix } \\
\text { strategy and export } \\
\text { performance of } \\
\text { Australian exporters }\end{array}$ & $\begin{array}{l}\text { empirical } \\
\text { investigation } \\
\text { of firms }\end{array}$ & Australia & Exporting firms & $\begin{array}{l}\text { Firm characteristics and environmental } \\
\text { characteristics impact significantly on } \\
\text { both overall performance and marketing } \\
\text { mix strategy adaptation by exporting } \\
\text { firms. The findings indicate that a strategic } \\
\text { approach must match the capability of } \\
\text { both the firm and its environment. }\end{array}$ \\
\hline 4 & Unnevehr, L.J. 2000 & $\begin{array}{l}\text { Food safety issues and } \\
\text { fresh food product } \\
\text { exports from LDCs }\end{array}$ & & LDCs & & $\begin{array}{l}\text { LDC exporters must learn to supply safe } \\
\text { products and to defend their interest in } \\
\text { transparent, equivalent standards. }\end{array}$ \\
\hline 5 & Julian, C.C. 2003 & $\begin{array}{l}\text { Export marketing } \\
\text { performance: a study } \\
\text { of Thailand firms }\end{array}$ & Survey & Thailand & $\begin{array}{l}\text { Small \& medium } \\
\text { Export firms }\end{array}$ & $\begin{array}{l}\text { Competition, commitment, export market } \\
\text { characteristics and product characteristics } \\
\text { are the statistically significant predictors of } \\
\text { export marketing performance for Thai } \\
\text { export firms. }\end{array}$ \\
\hline 6 & $\begin{array}{l}\text { Ahmed, Z., Julian, } \\
\text { C., Baalbaki, I., \& } \\
\text { Hadidian, T. } 2004\end{array}$ & $\begin{array}{l}\text { Export Barriers and } \\
\quad \text { Firm } \\
\text { Internationalization: A } \\
\text { Study of Lebanese } \\
\text { Entrepreneurs }\end{array}$ & Survey & Lebanon & $\begin{array}{l}\text { Manufacturing } \\
\text { firms }\end{array}$ & $\begin{array}{l}\text { Most manufacturers perceive lack of } \\
\text { government assistance, competition from } \\
\text { firms in foreign markets, the need to } \\
\text { modify pricing and promotion policies, } \\
\text { high foreign tariffs in export markets, and } \\
\text { the lack of capital to finance expansion } \\
\text { into foreign markets as the major barriers } \\
\text { to export. }\end{array}$ \\
\hline 7 & $\begin{array}{l}\text { Tesfom, G., Lutz, } \\
\text { C. \& Ghauri, P. } \\
2004 .\end{array}$ & $\begin{array}{l}\text { Comparing export } \\
\text { marketing channels: } \\
\text { developed versus } \\
\text { developing } \\
\text { countries }\end{array}$ & $\begin{array}{l}\text { Exploratory/ } \\
\text { model }\end{array}$ & $\begin{array}{l}\text { Netherlands, } \\
\text { Uganda \& } \\
\text { Eritrea }\end{array}$ & & $\begin{array}{l}\text { Lack of knowledge to locate foreign } \\
\text { market opportunities, lack of specific } \\
\text { information on agents \& distributers, lack } \\
\text { of experience in planning \& executing } \\
\text { exports, lack of management exposure to } \\
\text { other cultures \& methods of doing } \\
\text { business, lack of personnel trained \& } \\
\text { qualified in export marketing, inability to } \\
\text { self-finance exports, lack of export market } \\
\text { research \& information. }\end{array}$ \\
\hline
\end{tabular}




\section{Continued}

Morgan, N.,

8

Katsikeas, C. \&

Vorhies, D. 2011

Lages, L. \&

9 Montgomery, D. 2004

10

Zou, S., Fang, E. \& Zhao, S. 2003

Henson, S. \&

Loader, R. 2001

Barriers to

Agricultural

Exports from

Developing

Countries: The Role of

Sanitary and

Phytosanitary

Requirements
Survey

SME

Exporters

Marketing strategy adaptation to the foreign market is particularly noted in firms exporting to the most developed markets, rather than in firms exporting to the most competitive environments.
China

Exporters

Developing

countries

International

12

Sager, H. 2014 marketing in India:

prospects and

challenges
Effective implementation of planned export marketing strategy contributes to export market and financial performance, and that marketing capabilities play an important role in enabling effective marketing strategy implementation in export venture operations.

Support to the RBV view in the export marketing context and shed light on factors that affect Chinese exporters' performance.

SPS measures are a major factor influencing the ability of developing countries to exploit export opportunities for agricultural and food products in developed country markets; To a large extent this rejects poor access to compliance

Agri-export resources, including scientific and technical expertise, information and finance. The incompatibility of SPS requirements and production and/or marketing methods in developing countries is also a major factor affecting access to developed country markets.

Low marketing education. Presences foe foreign products and low patronage for non-essential products, high cost of production, inadequate infrastructures. Few competitive opportunities, excessive International government regulations and interference, marketing Political instability and civil unrest. There are prospects for improvement in the nearest future based on the high growing Population of most development countries. Attractive government incentives, growing affluences to mention but a few. 


\section{Continued}

Bozkurt, O. \& Esen, S. 2014

14

Bharti, A. 2014

Kuppusamy, J. \&

Anantharaman, R. 2014

Karelakis, C.,

Mattas, K. \&

Chryssochoidis, G. 2008

Siringoringo, H., Prihandoko,

Tintri, D. \&

Kowanda, A. 2009

\section{The Impact of}

Exporter

Small-Business

Enterprise Factors on

their own Export

Performance and Costs

Examining market

challenges

pertaining to cold chain

in the frozen food

industry in Indian retail

sector

Examining SME

Internationalization

Motives as an
Extension of
Competitive
Strategy

Descriptive

India

Frozen

food

A critical review of

arriers to export

business

Exploratory International

all

(knowledge, finance, human resource,

marketing, market research, benefits, risks

and cost) and external (payment,

competition, political and economic condition, customers, currency risk, political and economic risk).

Firms pursuing internationalization proactively are mainly influenced by favorable perceptions of their environment and their current performance. SMEs using a differentiation strategy based on unique marketing skills in conjunction with these circumstantial influences were more likely to pursue internationalization proactively.

Three clearly distinct clusters were formed. The results indicate that export problems are likely to occur in firms that are more passive in terms of export activities than in firms that adopt active and competitive export postures.

The export problems are: competition, long duration of export document process, product quality, export barrier from country destinations, low capability in high production, delay in transportation, communication barrier, government agencies that presume become barrier, lack of Problems faced by small and medium business in

Descriptive Indonesia exporting products
SME international market knowledge, barrier of exporters entering international market, export administrative procedures, inefficient production cost, unofficial fee in export documents processing, incapable to supply product in time, lack of knowledge in transaction method, limitation of destination country, time limitation in cargo, and delay of shipping. 


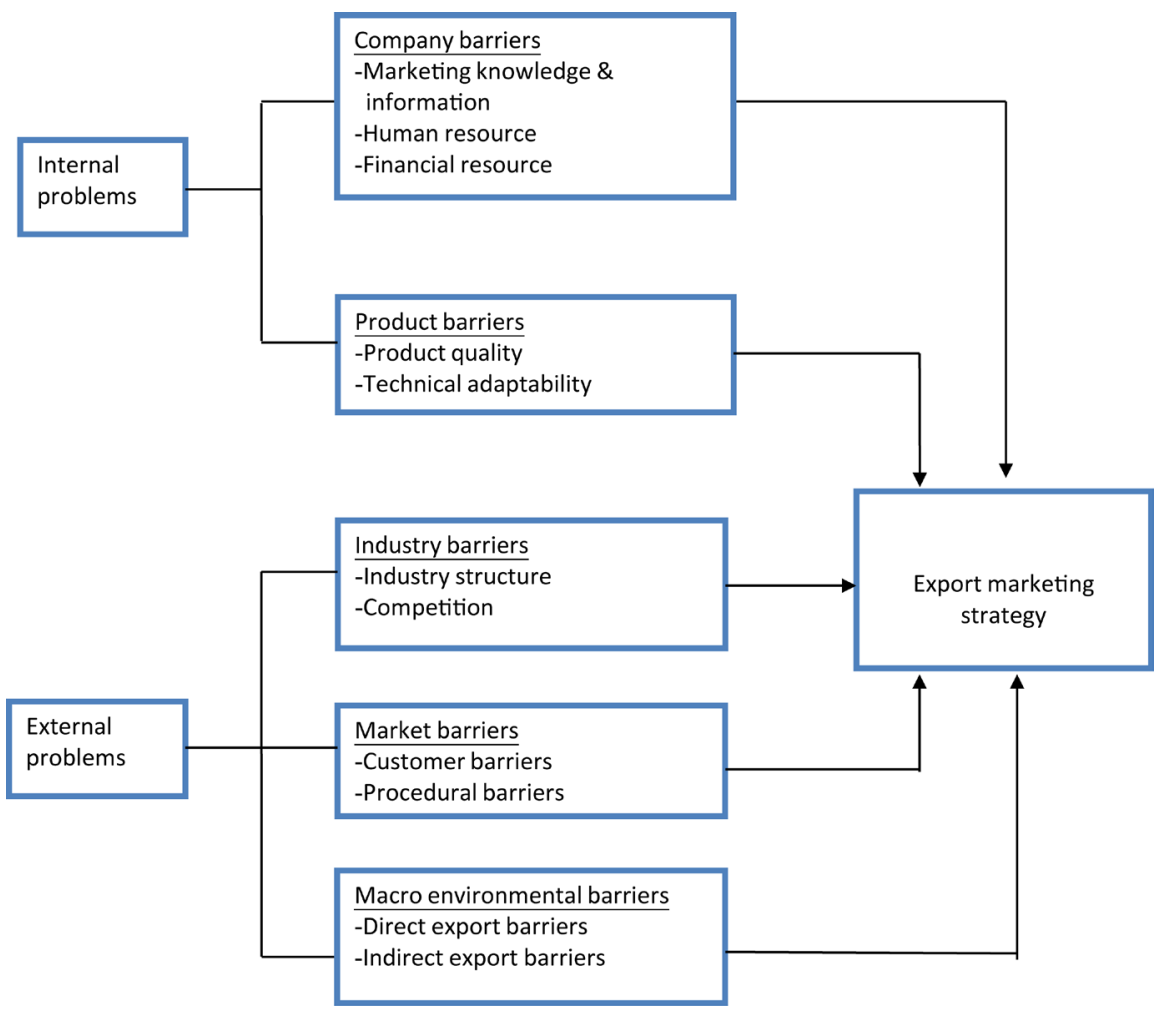

Figure 1. Conceptual framework. Source: Based on Tesfom and Lutz (2006).

\section{Literature Review}

\subsection{Export Marketing}

Export marketing is the most popular mechanism by which firms engage with international markets, understanding the drivers of export market performance is a key to explaining firms' international competitiveness [8]. Export market development is becoming more a matter of survival rather than a matter of choice for many firms in the world [9].

Continued globalization of the world's economies and intensifying worldwide competition has stimulated an ever-increasing number of firms to internationalize [8].

Exporting plays a vital role in the world and has countless benefits for firms and countries. Exporting is a fundamental strategy in ensuring firm's survival or growth, and firms may achieve competitive advantage in international markets with a positive influence on current and future export performance and so, many companies recently allocate more attention and resources in order to export their products to foreign markets [10].

Integration into global markets offers the potential for more rapid growth and poverty reduction for poorer countries [11].

\subsection{Concepts in Vegetable and Fruit}

Horticulture is derived from two Latin words hortus = garden and cultura = cultivation. It is a science and art of growing fruits, vegetables, flowers, shrubs, and 
trees [12].

Horticulture includes the growing of fruit (especially tree fruits), known as pomology; production of vegetable crops, called olericulture; production of flowers, termed floriculture; and ornamental horticulture, known also as landscape gardening, which includes the maintenance and design of home grounds, public gardens and parks, private estates, botanical gardens, and recreational areas such as golf courses, football fields, and baseball diamonds [12].

Horticulture industry mainly consists of the production of fruits, vegetables and flowers. The demand for these crops is moving beyond the use for special occasions and becoming a more regular decorative and consumption goods for every income groups [13].

\subsection{Characteristics of Vegetable and Fruit Marketing}

Being produced both by commercial and smallholder farmers vegetable and fruit marketing is influenced by a number of factors that can be attributed to production, product, and market characteristics (Kohl and Uhl 1985, cited in Adugna 2009) identified these attributes as:

1) Perishability: as vegetable and fruit are highly perishable, they start to lose their quality right after harvest and continued throughout the process until they are consumed. For this purpose, extensive marketing channels, facilities and equipments are vital. This behavior of vegetables and fruits exposed the commodity not to be held for long periods and fresh produce from one area is often sent to distant markets without a firm buyer or price. Prices may be negotiated while the commodities are enroute, and they are frequently diverted from their original destination of a better price can be found. Sellers might have little market power in determining a price. As a result, a great deal of trust and informal agreements are involved in marketing fresh vegetables and fruits. The urgent, informal marketing processes often leads to disputes between buyers and sellers of fresh fruits and vegetables. Producers are normally price takers and are frequently exposed for cheating by any intermediary.

2) Price/Quantity Risks: Due to perishable nature and biological nature of production process there is a difficulty of scheduling the supply of fruits and vegetables to market demand. The crops are subjected to high price and quantity risks with changing consumer demands and production conditions. Unusual production or harvesting weather or a major crop disease can influence badly the marketing system. While food-marketing system demands stable price and supply, a number of marketing arrangements like contract farming provide stability.

3) Seasonality: Vegetables and fruits have seasonal production directly influencing their marketing. Normally they have limited period of harvest and more or less a year-round demand. In fact, in some cases the cultural and religious set up of the society also renders demand to be seasonal. This seasonality also worsened by lack of facilities to store.

4) Product Bulkiness: Since water is the major components of the product, it 
makes them bulky and low value per unit that is expensive to transport in fresh form every time. This, therefore, exposed farmers to lose large amount of product in the farm unsold [14].

According to Dixie (2005), cited in Alazar (2007), horticulture products are perhaps mostly easily defined as what they are not. They are not cereals or the major industrial crops. Generally, but not exclusively, they are not staple crops. Important characteristics of horticultural crops are that they are mainly eaten for their contribution to the flavor and interest of food; are basic food commodities; consumption level vary depending on the selling price; are not traded in large volumes and there is a limited market; are perishable; are traded in a very free market where price is determined by supply and demand [14].

\subsection{Export Marketing Challenges}

Leonidou (1995) defined export barriers as:

"The attitudinal, structural, operational, and other constraints that hinder the firm's ability to imitate, develop, or sustain international operations." [15].

Export problems or barriers are defined as those constraints that hinder the ability of firm to initiate, develop or maintain export marketing activities of the firm [16].

Different researchers categorized export marketing problems into different categories. Some of them grouped export problems in to "internal" and "external" barriers [3] [17]. Delgado (2006) identified export problems as: production related; processing/marketing related; and economic and political environment. Clarke (2013) generated list of export impediments and grouped them into "generic", "product specific" and "market specific".

Karelakis (2008) classified export problems into four groups: "internal-domestic"; "internal-foreign"; "external-domestic"; and "external-foreign" [18].

Bezabih and Hadera (2007) identified the major constraints of marketing as lack of markets to absorb the production, low price for the products, large number of middlemen in the marketing system, lack of marketing institutions safeguarding farmers' interest and rights over their marketable produces (e.g., cooperatives), lack of coordination among producers to increase their bargaining power, poor product handling and packaging, imperfect pricing system, lack of transparency in market information system mainly in the export market [19].

World Bank (2004) identified the major constraints in the Ethiopian high value export products as; high freight cost and insufficient cargo space, lack of railway transport system, insufficient airport facilities, existence of illegal traders, poor packaging systems, lack of skilled manpower, insufficient pre and post-harvest infrastructure facilities, access to bank loan, and lack of comprehensive market study [20].

Severe production seasonality, seasonal price fluctuations, poor pre- and post-harvest handling, prevalence of pest and diseases, lack of storage are some of the critical problems encountered vegetable and fruit production in Ethiopia [14]. 
This study will focus on the classification of Tesfom and Lutz (2006) to further assess the appropriateness of the problems in the vegetable and fruit export marketing.

\subsubsection{Internal Problems}

Leonidou (2004) defined internal problems or barriers as:

"The constraints associated with organizational resources/capabilities and company approach to export business" [21].

These problems are categorized as those which are directly related to the controllable issues within the firm itself [21].

Tesfom and Lutz (2006) classified internal barriers further in to "company barriers" and "product barriers".

Company barriers influence their choice of marketing strategy and ability to execute that marketing strategy (Porter (1985), cited in Tesfom and Lutz (2006); O'Cass and Julian 2003). Key assets and skills of a company constitute its source of competitive advantage. Company barriers categorized under: marketing knowledge and information, financial resources and human resources [3] [9] [17] [18] [22].

Marketing knowledge and information problems are about lack of knowledge of foreign markets, business practices, and competition; and lack of management to generate foreign sales. Lack of knowledge to locate foreign opportunities and promising markets is perceived to be a major barrier to export from developing countries [3] [4] [8] [11] [17] [18] [22] [23] [24]. According to Lumpkin et al. (2005), expanding the scale of horticulture production is often hindered by lack of market access and market information.

Distribution is a major problem area in exporting. Many exporters in developing countries lack information about marketing channels and fail to establish marketing networks [3] [4].

Deficient advertising and promotion programs are also mentioned as other factors that constrain export activities [24].

Financial problem is one of the company barriers. Many exporting companies in developing countries cannot operate for lack of adequate working capital, which endanger the entire production operation and adds cost [3] [4] [15] [17] [18] [22] [25].

Human resource barrier is the key problem which holds back the success of the company. Export marketing activities depend on the attitudes and characteristics of the managers. Export marketing knowledge problems can be attributed to a large extent to the lack of trained and experienced human resources. A company that takes into account the requirements for international activities in its human resource management practices, particularly for its managerial and professional employees is more likely to do better in its export attempts [3] [4] [17] [18] [22] [25].

"Product problems are related to quality and technical requirements of the targeted export market segment, such as export product design, style, quality, 
packaging and labeling requirements and product adaptation or modification" [24].

Cook (1983), cited in Tesom and Lutz (2006), put that product characteristics affect the competitive advantage and influence the choice between an offensive and a defensive export strategy. The product barriers that influence the export marketing strategy of the firm could be grouped into quality and technical adaptability.

Quality barriers are related with packaging, meeting importers quality standards and establishing the suitable design and image for export markets. There are different quality standards in developing countries. Therefore, fulfilling those standards is mandatory for any exporting company in order to be competitive in the market [3] [4] [11] [17] [18] [22] [26] [27] [28].

In addition, Bharti (2014) identified the challenges for the quality of perishable export products in developing countries as: viability of cold chain; existing facilities are outdated and poorly maintained; and low awareness and demand for cold chain services. Cold chain plays the very vital role in reserving the quality of perishable products like vegetable and fruit export.

Technical/adaptation barrier is another important barrier. Successful firms adapt their products to foreign markets. Most of the problems related to technical adaptability are due to a lack of knowledge of market requirements or a lack of resources to meet the requirements: poor quality control techniques, poor quality of raw material, packaging and labeling requirements, product design and specification. In addition, product diversification is a barrier to internationalization [3] [4] [22].

\subsubsection{External Problems}

External problems or barriers are those barriers which are rooted in the external environment and the firm itself has no control over the consequences of such problems. These problems are also referred to as macro environment barriers or industrial barriers [3] [17].

Tesfom and Lutz (2006) further classified external barriers in to "industry barriers", "market barriers" and "macro environmental barriers".

Industry barrier is the first category of external problems. The intensity of exporting activities and the nature of export marketing strategies differ considerably across industries. Porter (1985) and Kerin et al. (1990), cited in Tesfom and Lutz (2006), noted that the difference among industries is due to the varying nature of industries. In order to develop a proper export marketing strategy, the differences between market systems, firm sizes and presence of foreign competitors across markets should be taken into account [3] [17].

Industry structure is one of the industry barriers which consists of firm size/economies of scale; lack of new technology; unprepared to face large MNCs; unreliability in raw material supply. The size of the firm is a key determinant of the propensity to export. The larger the firm, the greater the size advantage over the smaller firms; and this will usually have a positive impact on the export activity. 
Another important factor for exporting firms in developing countries is the supply of raw materials and inputs. They face unreliability in their supplies either from other domestic firms or from abroad [3] [4].

Competition barrier is another category of industry barriers. Competition should not be considered as a barrier if there is equal information exists among competitors in the market. However, in practice information on export opportunities is costly and not easily available. Therefore, lack of such information demotivates the firm to go for export and to withstand the existing competition with different exporters around the world [3] [4] [15] [18] [25] [26]. The competition barrier includes meeting foreign competitor prices; withstanding with aggressive competitors in the foreign market; lack of competitive prices; and fierce competition in export markets. Especially firms with limited financial and human resources are affected with it [3] [4].

"Export market barriers are factors that affect the export marketing strategy related to customer barriers and procedural barriers" [3].

Customer barriers stem from the customer's perception of product characteristics. An important issue here is that in addition to specific quality problems, exporters from developing countries face the poor image/goodwill of their country. In addition, bad image of products in the foreign market and insufficient foreign demand; language and culture differences; and country of origin effect are the major problems faced with the customers' preferences [3] [11] [25].

Procedural barriers are among the export market barriers. Exporting requires knowledge about export procedures. The time and paperwork required to comply with foreign and domestic market regulations is mostly lengthy. Not only government organizations but also other private organizations such as banks, shipping organizations and insurance companies, have their own procedures. Lack of information about export procedures and in particular for inexperienced managers foreign documentation and paper work may is very difficult to cope with. In addition, delay of payments; procedural complexity of paperwork; and delay in duty drawbacks are among the major procedural barriers that affect the exporting process [3].

"Macro environment barriers are one of the external barriers. These are factors beyond the firm's control; which further classified in to direct and indirect export barriers" [3].

Direct export barriers include tariff and non-tariff barriers; cost of transportation; inadequate diplomatic support; lack of export promotion and assistance from the government; complex government bureaucracies; infrastructure; and special customs requirements [3] [8] [15] [18] [25] [27].

Naidu et al. (1997), cited in Tesfom and Lutz (2006), described that exporting companies suffer because of the inadequacy of government export promotion policies. This includes lack of gathering and provision of information on available export opportunities and ineffective promotion of the country's exports to abroad.

Indirect export barriers are rooted in the macro-economic policy of the country 
and international trade agreements. They include: exchange and interest rate uncertainties; international trade agreements; foreign exchange rate policy [3] [25]. International trade agreements are good for the exporter but they can also discriminate against third party traders [3].

\section{Research Methodology}

\subsection{Research Design}

Descriptive research design was used to analyze demographic and some points on the structured questionnaires (Annex); in addition, the export data of the growers is analyzed quantitatively. Exploratory research design has been employed to analyze the qualitative part of the findings; which include search of literature and interviews.

\subsection{Population and Sampling}

A survey from the already existing 20 active commercial growers in the export was targeted which are located in Hawassa, Koka, Meki, Ziway, Debrezeit, Holeta, Sululta, Sendafa and Sebeta. The list of these commercial growers is obtained from Ethiopian Horticulture Development Agency (EHDA). There are many small-scale farmers, who are engaged in the vegetable and fruit export; especially for Djibouti and Somalia market. However, since the study focuses on commercial growers who are exporting to Europe and Middle East market, the study did not take into consideration small-scale farmers. Therefore, all active export commercial vegetable and fruit growers were considered. In addition, 8 major stakeholders who are directly involved in the value chain activities were included in the study.

\subsection{Data Source and Data Collection Method}

Both primary and secondary data sources were used for the study. The primary data sources were all commercial growers and the selected stakeholders of the sector. These data were collected through questionnaires and interviews. Questionnaires were developed for the selected vegetable and fruit exporting companies and as well as for the major stake holders. Structured questionnaires were given to each grower's general managers, marketing managers, farm managers and/or production managers. The data was collected from May 20, 2014 to June $5,2014$.

In addition to the questionnaires, interviews were carried out especially for the stakeholders in order to identify the root challenges in the export marketing process.

EHDA is the major source of secondary data especially for the export volume and sales of exporters. In addition, articles, journals, reports, websites... were cited for the reviewing related literatures.

The questionnaire is developed to collect significant information relating to various export challenges of the Ethiopian vegetable and fruit commercial exporting 
growers. The questionnaire is developed thorough review of relevant literature for identifying the various export challenges. Finally, a structured questionnaire with 40 questions is prepared on five different categories of challenges. The survey was conducted by a five-point Likert scale which is developed ranging from 1; "Strongly disagree", 3; "neither agree nor disagree" and finally to 5; "Strongly agree".

In this study, personal interview was conducted. For this, experts from 8 stakeholders of the sector were interviewed. In addition, an interview was held with 4 selected growers to identify additional challenges which are not listed in the questionnaire. The interviews were recorded and regular contact has been maintained with the respondents in order to extract and clarify more details from them. The format of the interview was semi-structured where possible additional questions will be also asked relating to the question being discussed. Therefore, a list of questions was prepared and discussed with the officials of the organizations.

\subsection{Methods of Data Analysis}

Both quantitative and qualitative analysis techniques were employed. The quantitative technique is more important to analyze the current status and trends of the export of the industry. Moreover, the questionnaires have been analyzed using quantitative technique. Qualitative technique was employed to analyze the interviews. The data has been analyzed and presented using SPSS, Excel spreadsheet, tabulation, charts and graphs.

The five-point Likert-scale questionnaires were analyzed by determining the cutoff value of the points. The Problems with mean score of greater than 3.5 were considered most important in the exporting activities of the firms; mean scores between 2.5 and 3.5 were considered as moderately important and problems with mean score lower than 2.5 were considered as low degree of importance. The output of the interviews held with selected growers and stakeholders has been jot down and briefly discussed in the findings part of the study.

Descriptive statistics was performed using SPSS version 20 including central tendency measurements; like mean, mode, frequency, and median has been used to analyze and interpret the data. The data has been coded and analyzed using SPSS 20. Descriptive statistics such as percentage was conducted subsequent to the validation and reliability process to ascertain the percentages of nominal variables.

\subsection{Data Reliability and Validity}

The reliability analysis is done using SPSS 20. Cronbach's alpha was used to analyze the reliability of the data. A pilot test on 5 respondents has been considered before the actual data collection begun and a Cronbach alpha value of 0.887 was observed which is above the cutoff value of 0.70 . After collecting from all the growers, a Cronbach's alpha value of 0.849 was observed from 40 items 
being considered. Therefore, the data is reliable and internally consistent.

For this study, content validity (face validity) has been selected to assess the validity of the data. Since the study covered all active vegetable and fruit commercial growers, it is representative of the universe. During the pilot test, there were 47 Likert-scale questions but after discussing with the selected 5 respondents, 7 of the questions were not relevant and discarded. Therefore, the content validity of the data is good.

\section{Data Presentation and Analysis}

The growers' perception of export problems depending on exporting experience. Growers with lower than five years of experience are more affected by both the internal and external barriers than that of more experienced growers. The average score of internal barriers by less experienced growers was 3.19 (company barriers $=3.13$ and product barriers $=3.26$ ); and by more experienced growers was $2.91($ company barriers $=2.88$ and product barriers $=2.95)($ Table 2$)$.

Table 2. Response to the importance of exporting problems by category.

\begin{tabular}{|c|c|c|c|c|}
\hline No & Items & $\mathbf{N}$ & Mean & $\begin{array}{c}\text { Std. } \\
\text { Deviation }\end{array}$ \\
\hline & Total average of barriers & 20 & 3.13 & 0.425 \\
\hline 1 & Internal barriers & 20 & 3.07 & 0.576 \\
\hline 1.1 & Company barriers & 20 & 3.02 & 0.786 \\
\hline 1.1 .1 & Marketing knowledge barriers & 20 & 2.81 & 1.069 \\
\hline 1.1 .2 & Financial barriers & 20 & 3.10 & 0.925 \\
\hline 1.1 .3 & Human resource barriers & 20 & 3.40 & 0.788 \\
\hline 1.2 & Product barriers & 20 & 3.12 & 0.665 \\
\hline 1.2 .1 & Quality barriers & 20 & 3.55 & 0.449 \\
\hline 1.2 .2 & Technical adaptation barriers & 20 & 2.91 & 0.856 \\
\hline 2 & External barriers & 20 & 3.20 & 0.340 \\
\hline 2.1 & Industry export barriers & 20 & 3.37 & 0.670 \\
\hline 2.1 .1 & Industry structure & 20 & 3.19 & 0.612 \\
\hline 2.1 .2 & Competition & 20 & 3.73 & 0.910 \\
\hline 2.2 & Export market barriers & 20 & 2.74 & 0.316 \\
\hline 2.2 .1 & Customer barriers & 20 & 2.20 & 0.470 \\
\hline 2.2 .2 & Procedural barriers & 20 & 3.47 & 0.854 \\
\hline 2.3 & Macro environment barriers & 20 & 3.49 & 0.546 \\
\hline 2.3 .1 & Direct export barriers & 20 & 3.65 & 0.555 \\
\hline 2.3 .2 & Indirect export barriers & 20 & 3.45 & 1.099 \\
\hline
\end{tabular}

Source: Survey data, 2014. 
Less experienced growers rated external barriers 3.24 (industry barriers $=3.39$; export market barriers $=2.78$; and macro-environmental barriers $=3.56$ ); whereas more experienced growers rated the external barriers 3.15 (industry barriers = 3.33; export market barriers $=2.70$; and macro-environmental barriers $=3.42$ ).

In both cases, macro-environmental barriers are rated higher than other categories. However, it was rated as most important barrier by less experienced growers and moderately important by more experienced barriers.

The total average of barriers is rated 3.22 by less experienced growers; which is greater than the total average of more experienced growers (3.03) (Table 3).

As shown in the above table, local investors are highly affected by the listed challenges (total average of barriers $=3.53$ ); whereas foreign investors (3.07) and joint ventures (2.60) are affected moderately. In all the three scenarios, companies are more affected by external barriers (3.20) than that of internal barriers (3.07) (Table 4).

In addition to the above analyzed structured questionnaires, the export challenges raised by the stakeholders and the selected commercial growers are listed as follows.

1) Management commitment problem of growers. Some of the local investors are not fully committed to run the business. They do not put their utmost effort to export their products.

2) Lack of technological advancement and awareness; this problem is especially witnessed on Ethiopian owned companies. Many of these growers do not provide right raw materials and inputs like fertilizers and chemicals. This is due to their lack of awareness.

3) Financial problems to run the farm operations smoothly which in turn will affect the production and quality of the products. For example, the irrigation system of some local investors is furrow irrigation which will expose the produce

Table 3. Growers' perception depending on exporting experience.

\begin{tabular}{|c|c|c|c|c|c|c|c|c|c|}
\hline \multicolumn{2}{|c|}{$\begin{array}{c}\text { Exporting } \\
\text { experience in years }\end{array}$} & \multirow{2}{*}{$\begin{array}{c}\text { Company } \\
\text { barriers }\end{array}$} & \multirow{2}{*}{$\begin{array}{c}\text { Product } \\
\text { barriers } \\
3.26\end{array}$} & \multirow{2}{*}{$\begin{array}{c}\text { Internal } \\
\text { barriers } \\
\text { (tot. av) }\end{array}$} & \multirow{2}{*}{$\begin{array}{c}\begin{array}{c}\text { Industry } \\
\text { export } \\
\text { barriers }\end{array} \\
3.39\end{array}$} & \multirow{2}{*}{$\begin{array}{c}\begin{array}{c}\text { Export } \\
\text { market } \\
\text { barriers }\end{array} \\
2.78\end{array}$} & \multirow{2}{*}{$\begin{array}{c}\begin{array}{c}\text { Macro } \\
\text { env'tal } \\
\text { barriers }\end{array} \\
3.56\end{array}$} & \multirow{2}{*}{$\begin{array}{c}\begin{array}{c}\text { External } \\
\text { barriers } \\
\text { (tot. av.) }\end{array} \\
3.24\end{array}$} & \multirow{2}{*}{$\begin{array}{c}\begin{array}{c}\text { Average of } \\
\text { barriers }\end{array} \\
3.22\end{array}$} \\
\hline & Mean & & & & & & & & \\
\hline $\begin{array}{c}\text { Below } 5 \\
\text { years }\end{array}$ & $\mathrm{N}$ & 11 & 11 & 11 & 11 & 11 & 11 & 11 & 11 \\
\hline & $\%$ & $55.0 \%$ & $55.0 \%$ & $55.0 \%$ & $55.0 \%$ & $55.0 \%$ & $55.0 \%$ & $55.0 \%$ & $55.0 \%$ \\
\hline \multirow{3}{*}{$\begin{array}{c}\text { Above } 5 \\
\text { years }\end{array}$} & Mean & 2.88 & 2.95 & 2.91 & 3.33 & 2.70 & 3.42 & 3.15 & 3.03 \\
\hline & $\mathrm{N}$ & 9 & 9 & 9 & 9 & 9 & 9 & 9 & 9 \\
\hline & $\%$ & $45.0 \%$ & $45.0 \%$ & $45.0 \%$ & $45.0 \%$ & $45.0 \%$ & $45.0 \%$ & $45.0 \%$ & $45.0 \%$ \\
\hline \multirow{3}{*}{ Total } & Mean & 3.01 & 3.12 & 3.07 & 3.37 & 2.74 & 3.49 & 3.20 & 3.13 \\
\hline & $\mathrm{N}$ & 20 & 20 & 20 & 20 & 20 & 20 & 20 & 20 \\
\hline & $\%$ & $100.0 \%$ & $100.0 \%$ & $100.0 \%$ & $100.0 \%$ & $100.0 \%$ & $100.0 \%$ & $100.0 \%$ & $100.0 \%$ \\
\hline
\end{tabular}

Source: Survey data, 2014. 
Table 4. Companies' perception depending on ownership.

\begin{tabular}{|c|c|c|c|c|c|c|c|c|c|}
\hline \multicolumn{2}{|c|}{ Ownership } & \multirow{2}{*}{$\begin{array}{c}\begin{array}{c}\text { Company } \\
\text { barriers }\end{array} \\
2.85\end{array}$} & \multirow{2}{*}{$\begin{array}{c}\begin{array}{c}\text { Product } \\
\text { barriers }\end{array} \\
3.04\end{array}$} & \multirow{2}{*}{$\begin{array}{c}\begin{array}{c}\text { Internal } \\
\text { barriers } \\
\text { (tot. av) }\end{array} \\
2.94\end{array}$} & \multirow{2}{*}{$\begin{array}{c}\begin{array}{c}\text { Industry } \\
\text { export } \\
\text { barriers }\end{array} \\
3.17\end{array}$} & \multirow{2}{*}{$\begin{array}{c}\begin{array}{c}\text { Export } \\
\text { market } \\
\text { barriers }\end{array} \\
2.76\end{array}$} & \multirow{2}{*}{$\begin{array}{c}\text { Macro } \\
\text { env'tal } \\
\text { barriers }\end{array}$} & \multirow{2}{*}{$\begin{array}{c}\begin{array}{c}\text { External } \\
\text { barriers } \\
\text { (tot. av.) }\end{array} \\
3.19\end{array}$} & \multirow{2}{*}{$\begin{array}{c}\begin{array}{c}\text { Average of } \\
\text { barriers }\end{array} \\
3.07\end{array}$} \\
\hline & Mean & & & & & & & & \\
\hline \multirow[t]{3}{*}{ Foreign } & $\mathrm{N}$ & 13 & 13 & 13 & 13 & 13 & 13 & 13 & 13 \\
\hline & $\%$ & $65.0 \%$ & $65.0 \%$ & $65.0 \%$ & $65.0 \%$ & $65.0 \%$ & $65.0 \%$ & $65.0 \%$ & $65.0 \%$ \\
\hline & Mean & 3.92 & 3.47 & 3.69 & 4.00 & 2.83 & 3.27 & 3.37 & 3.53 \\
\hline \multirow[t]{3}{*}{ Local } & $\mathrm{N}$ & 5 & 5 & 5 & 5 & 5 & 5 & 5 & 5 \\
\hline & $\%$ & $25.0 \%$ & $25.0 \%$ & $25.0 \%$ & $25.0 \%$ & $25.0 \%$ & $25.0 \%$ & $25.0 \%$ & $25.0 \%$ \\
\hline & Mean & 1.85 & 2.78 & 2.31 & 3.08 & 2.43 & 3.17 & 2.89 & 2.60 \\
\hline \multirow{3}{*}{$\begin{array}{c}\text { Joint } \\
\text { venture }\end{array}$} & $\mathrm{N}$ & 2 & 2 & 2 & 2 & 2 & 2 & 2 & 2 \\
\hline & $\%$ & $10.0 \%$ & $10.0 \%$ & $10.0 \%$ & $10.0 \%$ & $10.0 \%$ & $10.0 \%$ & $10.0 \%$ & $10.0 \%$ \\
\hline & Mean & 3.01 & 3.12 & 3.07 & 3.37 & 2.74 & 3.49 & 3.20 & 3.13 \\
\hline \multirow[t]{2}{*}{ Total } & $\mathrm{N}$ & 20 & 20 & 20 & 20 & 20 & 20 & 20 & 20 \\
\hline & $\%$ & $100.0 \%$ & $100.0 \%$ & $100.0 \%$ & $100.0 \%$ & $100.0 \%$ & $100.0 \%$ & $100.0 \%$ & $100.0 \%$ \\
\hline
\end{tabular}

Source: Survey data, 2014.

to soil born diseases. Moreover, there will not be equal distribution of nutrients and water to the plants. This ultimately affects the quality and production of the produces.

4) Lack of accessible land and sea transport system in the country. There is no rail and sea transport in the country. It is due to the absence of refrigerated container in the ships, even though there is a start in this regard. Many of the products being exported are leafy vegetables and some light-weighted fruits and vegetables through air transport. The air transport is expensive to withstand the competition against the nearby suppliers of European market. In addition, shortage of cargo freighters to transport the produces to the destination market. Many of the growers are sending their produce through passenger crafts with no cold store facilities. It will have its own impact on the quality of the product. Moreover, there is shortage of cargo space after booking for the shipment.

5) Low awareness on the sensitivity of the sector among stakeholders. There is no much integration between the governmental and non-governmental actors of the vegetable and fruit export sector.

6) Seasonality of Ethiopian vegetable and fruit supply. Since many of the growers are growing out door, it is hard to keep promises with customers to supply year-round. It is not practical to grow in the rainy season. Therefore, the customers shift their face to the other countries' exporters to get a year-round supply.

7) Shortage of infrastructure. Breakage of electric power supply, lack of telecommunication services, and shortage of suitable roads. The shortage of power has an effect on the products shelf life and quality. Lack of internet and tele- 
communication services will cut growers' communication with their customers. As a result, there will be delay on their exporting activities.

8) Government organizations' bureaucracy and lack of work efficiency. Some government organizations are not efficient while delivering their services for the growers. Moreover, there is bureaucracy in some of them.

9) Different food safety certification requirements from different importers. Different importers and supermarkets demand different certifications, which takes much time until the certification offered. In addition, there is inconsistency demand from importers (customers). The product specification demand from importers varies from time to time.

10) Lack of potential markets. Locally owned companies do not have the habit of searching new potential markets. They expect some government organization will study for them.

11) World economic and political crisis. The economic crisis occurred in 2008/09 had an effect on the consumers' demand.

12) Shortage of inputs and expensive to procure. There are some importers of chemicals and fertilizers. Growers sometimes cannot get chemicals for sudden occurrence of diseases and insects which will affect the production and quality of the products. Moreover, the prices are untouchable because there is no as such competition between suppliers.

\section{Conclusions}

Increasing exports is widely regarded as important factor for the development and growth in developing countries. Exporters are contributors to the exports of the country which in turn raises the standard of living of the people of the country. Even though exporting companies play vital role for the economic development of the country, they are constrained by several export marketing problems. Different authors classified these problems into different categorization. Therefore, using classification given by Tesfom and Lutz (2006), all the discussed export marketing problems were classified into internal and external problems.

This study has identified export market problems encountered by Ethiopian vegetable and fruit commercial growers. The study found out that both internal and external barriers are moderately important challenges for the growers. The growers are highly affected by macro-environmental barriers which embrace infrastructure, currency fluctuation, and government offices bureaucracy. In the internal barriers, quality barriers were most important to the growers. Human resource and financial barriers were moderately important; marketing knowledge and technical adaptability were least important to the growers. It shows that many of the growers do not have a marketing knowledge and technical problems. However, local investors are highly affected by these problems.

With regard to the external barriers, export market barriers are less important barriers to most of the growers, which include customer and procedural barriers. Most of the growers are highly affected by procedural barriers, but customer 
barriers are least important barriers. Macro-environmental barriers are most important barriers for Ethiopian vegetable and fruit commercial growers. Industry barriers are moderately important barriers to the growers.

In addition, there are more problems identified through interview with stakeholders and growers. These include management commitment problem of growers; lack of technological advancement and awareness; financial problems to run the farm operations smoothly; lack of accessible land and sea transport system; low awareness on the sensitivity of the sector among stakeholders; seasonality of Ethiopian vegetable and fruit supply; shortage of cargo freighters; shortage of infrastructure; bureaucracy of government organizations; different food safety certification need from different importers; lack of potential markets; inconsistent demand from importers; world economic and political crisis; shortage of inputs; and lack of integration between different stakeholders of the sector.

\section{Recommendations}

Based on the findings of the study, the following recommendations are forwarded:

1) First and foremost, it is important for the commercial growers to identify their major challenges and incorporate in their export marketing strategy so that they will be ready to tackle these challenges and exploit the opportunities.

2) Most of the growers are being affected by the macro-environmental barriers which needs the direct and indirect involvement of different government organizations such as; the infrastructure, bureaucracy, customs regulations and transparency. Therefore, it is suggested that to create enabling policy environment and improve the service delivery reliability.

3) Air freight cost is the major cost to deliver the produces to the destination market. Therefore, it is suggested that to practice fair and competitive air freight cost so as to enhance the development of the sector and as well as for the economic development of the country. In addition, the Ethiopian Airline has to increase the cargo freighters to tackle the cargo space problems.

4) The government has to especially support locally owned growers in the area of market exploration and technical capacity building to enhance their involvement in the international market, since they are facing these problems.

5) The wellbeing of vegetable and fruit production is highly dependent on the quality and quantity of inputs. However, there is lack in availability of inputs and their price is expensive. Therefore, it is suggested to create new competitive input suppliers in the industry.

6) Different stakeholders of the sector including government organizations have to work hand in hand to support the growers. If there is integration between the stakeholders of the sector, the development of the sector will be enhanced.

7) It is suggested to recruit skilled and knowledgeable manpower in the production and marketing process. 


\section{References}

[1] Lumpkin, T., Weinberger, K. and Moore, S. (2005) Increasing Income through Fruit and Vegetable Production Opportunities and Challenges. Marrakech.

[2] IBIS (2013) World Industry Report C1112-GL: Global Fruit and Vegetables Processing.

[3] Tesfom, G. and Lutz, C. (2006) A Classification of Export Marketing Problems of Small and Medium Sized Manufacturing Firms in Developing Countries. International Journal of Emerging Markets, 1, 262-281.

https://doi.org/10.1108/17468800610674480

[4] Tesfom, G., Lutz, C. and Ghauri, P. (2004) Comparing Export Marketing Channels: Developed versus Developing Countries. International Marketing Review, 21, 409-422. https://doi.org/10.1108/02651330410547117

[5] Joosten, F., Boselie, D., Wolde, B. and Desalegn, L. (2011) Exporting Fruit and Vegetables from Ethiopia: Assessment of Development Potentials and Investment Options in the Export-Oriented Fruit and Vegetable Sector. Addis Ababa.

[6] Wiersinga, R.C. and de Jager, A. (2009) Business Opportunities in the Ethiopian Fruit and Vegetable Sector. Ministry of Agriculture, Nature and Food Quality.

[7] Digafe, T. (2013) Fruit and Vegetable Export of Ethiopia: Performance and Constraints. Birritu Magazine, No. 115.

[8] Morgan, N.A., Katsikeas, C.S. and Vorhies, D.W. (2011) Export Marketing Strategy Implementation, Export Marketing Capabilities, and Export Venture Performance. Journal of Academy of Marketing Science, 40, 271-289. https://doi.org/10.1007/s11747-011-0275-0

[9] O’Cass, M.A. and Julian, C.C. (2003) Examining Firm and Environmental Influences on Export Marketing Mix Strategy and Export Performance of Australian Exporters. European Journal of Marketing, 37, 366-384.

https://doi.org/10.1108/03090560310459005

[10] Moghaddam, F.M., Abu Bakar, A., Abdul Rasid, S.Z. and Darestani, H. (2011) The Influence of Export Marketing Strategy Determinants on Firm Export Performance: A Review of Empirical literatures between 1993-2010. International Journal of Fundamental Psychology and Social Sciences, 1, 26-34.

[11] Martinez, M.G. and Poole, N. (2004) The Development of Private Fresh Produce Safety Standards: Implications for Developing Mediterranean Exporting Countries. Journal of Food Policy, 29, 229-255. https://doi.org/10.1016/j.foodpol.2004.04.002

[12] Prasad, S. and Kumar, U. (2010) Principles of Horticulture. 2nd Edition, Agrobios, New Delhi, 1.

[13] http://www.intracen.org

[14] Adugna, G.T. (2009) Analysis of Fruit and Vegetable Market Chains in Alamata, Southern Zone of Tigray: The Case of Onion, Tomato and Papaya. M.Sc. Thesis, Haramaya University, Haramaya.

[15] Ahmed, Z.U., Julian, C.C., Baalbaki, I. and Hadidian, T.V. (2004) Export Barriers and Firm Internationalization: A Study of Lebanese Entrepreneurs. Journal of Management and World Business Research, 1, 11-22.

[16] Kaleka, A. and Katsikeas, C.S. (1995) Exporting Problems: The Relevance of Export Development. Journal of Marketing Management, 11, 499-515.

https://doi.org/10.1080/0267257X.1995.9964361 
[17] Liargovas, P.G. and Skandalis, K.S. (2008) Motives and Marketing Strategies of Greek Companies Exporting to South-East European Markets. South-Eastern Europe Journal of Economics, 2, 227-244.

[18] Karelakis, C., Mattas, K. and Chryssochoidis, G. (2008) Export Problems Perceptions and Clustering of Greek Wine Firms. EuroMed Journal of Business, 3, 6-22. https://doi.org/10.1108/14502190810873795

[19] Bezabih, E. and Hadera, G. (2007) Constraints and Opportunities of Horticulture Production and Marketing in Eastern Ethiopia. Drylands Coordination Group Report No. 46.

[20] World Bank (2004) A Review of Manufacturing Activities with High-Value Exports Growth Potential in Ethiopia: Market Structure, Costs, Constraints, Competition and Opportunities.

[21] Vohra, K. (2008) Export Marketing Problems of SMEs: The Case of Ludhiana Apparels and Textile Industry. Dissertation for MA Degree, The University of Nottingham, Nottingham.

[22] Delgado, C.L. (2006) Integration of Smallholders with Processors and Marketers of High-Valued Items. International Food Policy Research Institute, Washington DC.

[23] Timoty, L. (2008) Examining SME Internationalization Motives as an Extension of Competitive Strategy. Journal of Business and Entrepreneurship. Journal of Business and Entrepreneurship, 16, 46-65.

[24] Siringoringo, H., Prihandoko, T.D. and Kowanda, A. (2009) Problems Faced by Small and Medium Business in Exporting Products. Delhi Business Review, 10, 49-56.

[25] Kuppusamy, J. and Anantharaman, R.N. (2014) A Critical Review of Barriers to Export Business. SMART Journal of Business Management Studies, 10, 9-18.

[26] Julian, C.C. (2003) Export Marketing Performance: A Study of Thailand Firms. Journal of Small Business Management, 41, 213-221. https://doi.org/10.1111/1540-627X.00077

[27] Maertens, M. and Swinnen, J. (2009) Food Standards, Trade and Development. Review of Business and Economics, 54, 313-326.

[28] Reardon, T., Codron, J. and Busch, L. (2001) Global Change in Agrifood Grades and Standards: Agribusiness Strategic Responses in Developing Countries. International Food and Agribusiness Management Review, 2, 421-435. 